\title{
STRENGTHENING FOR ENTREPRENEURSHIP PROGRAM OF SORGHUM BASE AS FOOD ALTERNATIVE DURING THE PANDEMIC RECOVERY COVID-19
}

\author{
${ }^{1}$ Endang Noerhartati, ${ }^{2}$ Che Zalina Zulkifli, ${ }^{3}$ Pratiwi Dwi Karyati, ${ }^{4}$ Nugrahini Susantinah Wisnujati, \\ ${ }^{5}$ Iva Evry Robiyansah , ${ }^{6}$ Nia Saurina, ${ }^{7}$ Lusy Tunik Muharlisiani
}

\footnotetext{
${ }^{1}$ Department of Agroindustrial Technology, Universitas Wijaya Kusuma Surabaya, Indonesia ${ }^{2}$ Faculty of Arts, Computing and Creative Industry, Universiti Pendidikan Sultan Idris, Malaysia

${ }^{3}$ Department of Economic Development, Universitas Wijaya Kusuma Surabaya, Indonesia

${ }^{4}$ Department of Master Agribusiness, Universitas Wijaya Kusuma Surabaya, Indonesia

${ }^{5}$ Postgraduate Student, Department of Education Management, Unesa, Surabaya, Indonesia

${ }^{6}$ Department of Informatic Engineering, Wijaya Kusuma Surabaya University, Indonesia

${ }^{7}$ Department of English Education, Universitas Wijaya Kusuma, Surabaya, Indonesia

Email: ${ }^{1}$ endang_noer@uwks.ac.id, ${ }^{2}$ chezalina@ @sksk.upsi.edu.my, ${ }^{3}$ pratiwidwikarjati@uwks.ac.id,

wisnujatinugrahini@uwks.ac.id, ${ }^{4}$ iva.18012@mhs.unesa.ac.id, ${ }^{6}$ niasaurina@gmail.com,

lusy_fbs@uwks.ac.id
}

\begin{abstract}
Purpose: The purpose of this research was to find a solution during the pandemic recovery covid-19 with the strengthening of alternative food entrepreneurship sorghum.

Design/methodology/approach: The research method uses qualitative research methods in entrepreneurship, descriptive qualitative action research with data collection techniques in the form of observation and documentation, after the data collected is then analyzed statistically descriptive.

Findings: The results showed that sorghum can be used as a national food stock facing a crisis and pandemic covid-19, sorghum food stock in the form of grains, rice, flour, soft brand sorghum, and various processed sorghum. National sorghum food stock strategy includes strengthening clusters and production centers, silo utilization cooperation, socialization of various sorghum products, and strengthening Center of Sorghum Entrepreneur (CSE) and Sorghum Entrepreneurship Unit (SEU).

Research limitations/implications: State your limitation here. During the pandemic, the entrepreneurship program can't run well.

Practical implications: State your implication here. Whatever the condition, the entrepreneurship program must go on, so after pandemic finish, the member of program can runs a business.
\end{abstract}

Originality/value: This paper is original.

Paper type: Research paper.

Keyword: Strengthening, Pandemic Covid 19, Entrepreneurship Program, Sorghum, Food Alternative

Received: August $17^{\text {th }}, 2020$

Revised: September $16^{\text {th }}, 2020$

Published: September $30^{\text {th }}, 2020$

Strengthening for Entrepreneurship Program of Sorghum Base as Food Alternative During

The Pandemic Recovery Covid-19

Page | 300

Endang Noerhartati, Che Zalina Zulkifli, Pratiwi Dwi Karyati, Nugrahini Susantinah Wisnujati,

Iva Evry Robiyansah , Nia Saurina, Lusy Tunik Muharlisiani 


\section{INTRODUCTION}

Entrepreneurship is defined as an activity that involves the discovery, evaluation and exploitation of opportunities to market goods and services. Indonesia faces the pandemic covid 19 period, food product entrepreneurship is very important to maintain the stability and fulfilment of people's nutrition as an effort to maintain immunity. So far, the fulfilment of food in Indonesia is also imported from various countries, which currently cannot be carried out in order to cut off the possibility of spreading the corona virus from abroad. So it needs to be examined opportunities and challenges of fulfilling domestic food in Indonesia (Banerjee, 2020); (H. Wang, Zhang, Lu, \& Wang, 2020) . There was pandemic covid-19 period in Indonesia affecting various sectors, among them the food sector, so this research purposes to provide alternative solutions in case appear food crisis during the pandemic covid-19 by strengthening units sorghum entrepreneurship.

\section{METHODOLOGY}

The research method uses qualitative research methods in entrepreneurship, descriptive qualitative action research with data collection techniques in the form of observation and documentation, after the data collected is then analyzed statistically descriptive

\section{RESULTS AND DISCUSSION}

The Covid-19 mass pandemic scenario includes: (1) The epidemic handling and control period, so far all countries including Indonesia carry out activities of learning, working, and worshiping from home, always keeping a distance, always washing hands, keeping the environment clean, and always wearing a mask. Stop mass activities and close national borders, and continue to close every city, district and provincial border in Indonesia (Wu, Lin, Chien, \& Hung, 2011). (2) Crisis period, after the era pandemic it is likely that a crisis will occur, if the pandemic is more than 6 months. Impacts in various sectors including the food sector will occur, this will result in diminishing food stocks while each country concentrates on the country and is still in the process of recovery (Rizal \& Wedhaswary, 2020); (3) Socio-economic recovery period, in line with the rapid development of the pandemic covid 19, each country must prioritize public health, which in turn will have an impact on the socio-economic aspects. The Dcode 2020 analysis presents the sectors won and lost during a pandemic (Figure 1), it appears that food processing \& retailing are included in potential Winners, in addition to the oil \& gas, agriculture, e-commerce, ICT, personal \& health care sectors, and supply \& services medical. This can be the basis for the recovery of a country's socioeconomic conditions by presenting their respective characters (Baldwin \& Mauro, 2020).

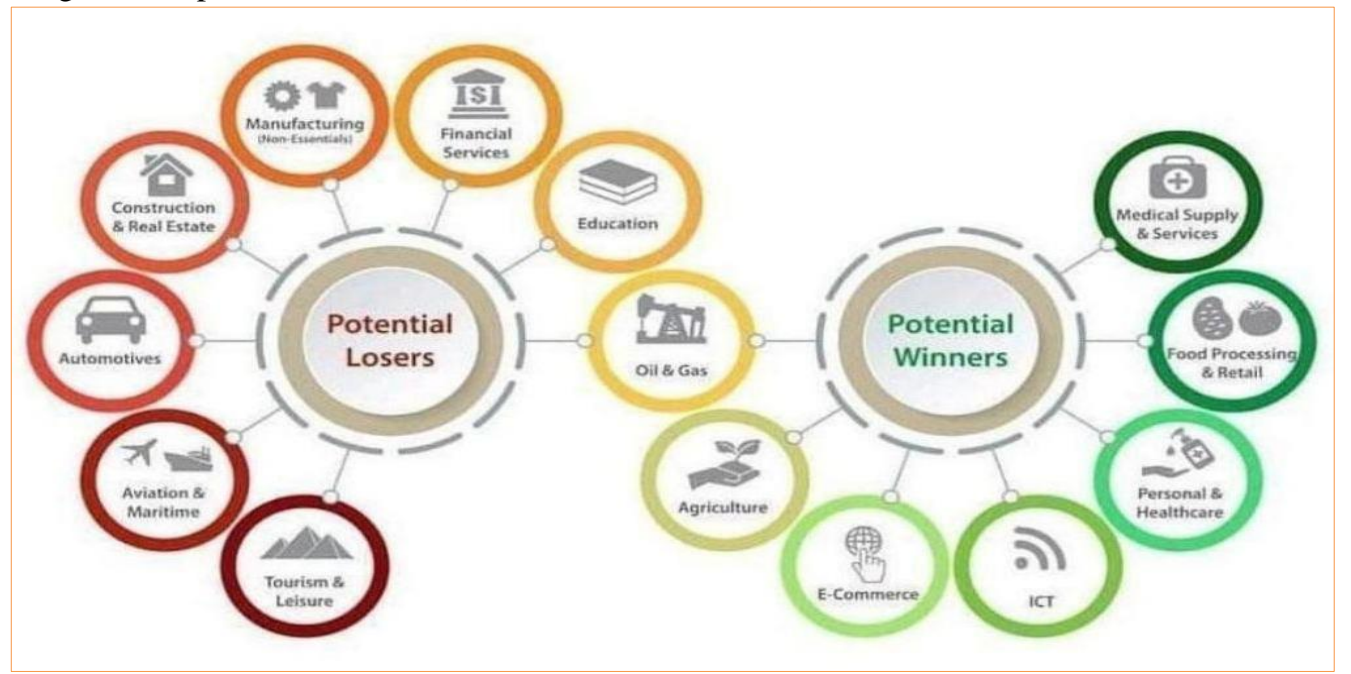

Figure 1. Decoding The Economics Of Covid-19: Potensial Winners \& Losers In The Short Term

Source: Dcode EFC Analysis (2020) 
Imports of Several Food Commodities (Jan-Nov 2018), presented in Figure 2. The largest final import value of food is wheat grain \& wheat flour machines US \$2.5 million and rice US \$1.03 M (Badan Pusat Statistik, 2019). Rice is the most strategically, this is related to the fact that rice is a staple food ingredient in Indonesia, so there must be an alternative food with nutritional value equivalent to rice.

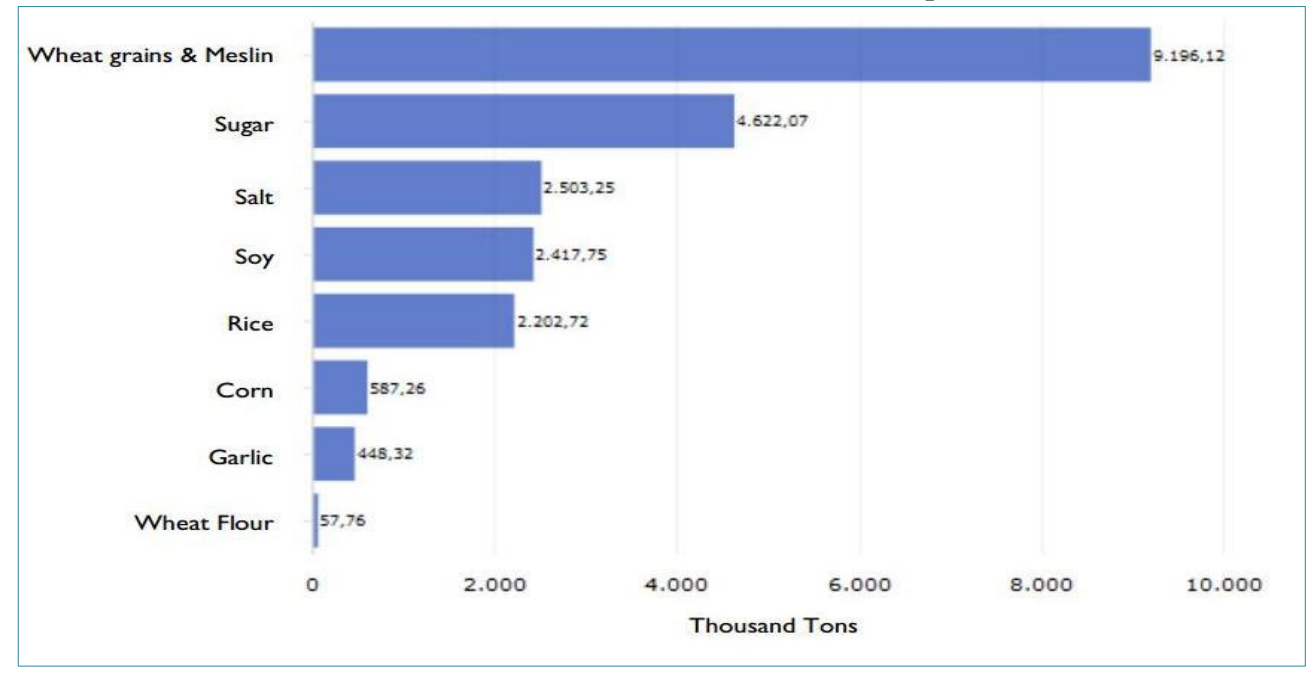

Figure 2. Import Some Food Commodities (Jan-Nov 2018)

Source: (Badan Pusat Statistik, 2019)

During the pandemic covid-19 had to sharpen the scale of national development priorities covering three main sectors: 1. Health, in December 2019 a new coronavirus pneumonia (COVID-19) appeared in Wuhan, China. Since then, this highly contagious COVID-19 has spread throughout the world, with a rapid increase in the number of deaths. Maintaining health is very important, WHO states that this is the sixth public health emergency of international concern, so the focus of a country's policy must be prioritized on health management policies, as an effort to take various preventative measures, including maintaining social distance, staying at home, and not touch our faces when outside the home. Lifestyle and healthy eating are important to protect immunity, and exercise; (2) Food, there are three keys to a healthy life while undergoing activities in the midst of the Covid-19 pandemic: (a) Eating resolution, having to consume a variety of foods. There are carbohydrates, proteins, vitamins, and minerals; (b) Exercise resolution, drink eight to ten glasses of water a day, then sunbathe for about 15 minutes at 8-10 am; (c) Mind and soul resolution, keep the mind calm and not easily panic; and (3) Science and technology in particular to support priorities (1) and (2), studies are needed specifically to support health and food priorities, where the wider community does not all understand how to prevent the transmission of the covid virus 19 (Adams \& Walls, 2020); (Baker, Farrokhnia, Meyer, Pagel, \& Yannelis, 2020); (C. J. Wang, Ng, \& Brook, 2020).

Specifically for food, national issues and issues related to food security include: (1) Food stock, ensuring food stocks are very important, especially staple food for rice. At this time it must be calculated correctly how much population and how much rice is needed each month, and for how long the food supply is sufficient; (2) Food diversification, to increase the amount of food needed to support national food stability, alternative foods are needed that can be produced from the country itself. (3) Consumption and nutrition patterns, it is very important to balance consumption and nutrition to maintain immunity and maintain it during activities at home, so as to avoid transmission of the virus; and (4) Food independence and independence, related to maintaining a country's food stability which must be available and can also maintain price stability. The implementation of a pandemic emergency period exceeds the 6th month or more, it is estimated that there will be problems with food availability. A crisis situation can occur because the possibility of imports will be reduced and hampered due to export countries experiencing food problems as well. National food stock will shrink. This situation is soon followed by a recovery period towards a new pattern or normal balance. According to experts, the recovery time for economic conditions is about 1-2 years (Bolarinwa, Ogundari, \& Aromolaran, 2020); (Campi, Dueñas, \& Fagiolo, 2020); (Martin et al., 2020).

A critical period and recovery, alternative food sources become the foundation in providing food needs besides rice. Sorghum is one that is used as part of efforts to prepare national food stocks. The potential of sorghum as an alternative food is supported by its nutritional characteristics, namely: Calorie

Strengthening for Entrepreneurship Program of Sorghum Base as Food Alternative During

The Pandemic Recovery Covid-19

Page | 302

Endang Noerhartati, Che Zalina Zulkifli, Pratiwi Dwi Karyati, Nugrahini Susantinah Wisnujati, Iva Evry Robiyansah , Nia Saurina, Lusy Tunik Muharlisiani 
content of rice $360 \mathrm{cal}$ and sorghum $332 \mathrm{cal}$; The protein content of rice is $6,8 \mathrm{~g}$ and sorghum $11 \mathrm{~g}$; rice fat $0.7 \mathrm{~g}$ and sorghum $3.3 \mathrm{~g}$; carbohydrate rice $78.9 \mathrm{~g}$ and sorghum $73 \mathrm{~g}$; Calcium rice $6 \mathrm{mg}$ and sorghum $28 \mathrm{mg}$; Iron rice $0.8 \mathrm{mg}$ and sorghum $4.4 \mathrm{mg}$; Rice phosphorus $140 \mathrm{mg}$ and sorghum $287 \mathrm{mg}$; and vit B1 rice 0.12 $\mathrm{mg}$ and sorghum $0.38 \mathrm{mg}$. Another advantage of sorghum is gluten free, more fiber, including policosanol \& plant-sterols which can reduce LDL cholesterol, include tannin as anti-oxidant, and low glycemic index (Ardabili, Zakaria, \& Zare, 2015); (Noerhartati, 2018).

All parts of sorghum plants can be used as products of entrepreneurship, namely in the form of grains, rice, flour, soft brand sorghum, and various processed sorghum. So in the context of strengthening the recovery period for Covid Pandemic-2019, with the National Sorghum Food Stock Strategy, which is carried out in several stages, namely: ((1) Strengthening clusters and sorghum producing production centers must be carried out as an effort to strengthen the national food stock; (2) Cooperation in the use of silos, in order to maintain the quality of sorghum seeds, it is necessary to have long-lasting and suitable storage for seeds, including silos, the use of silos must carry out collaborations which are usually used for rice only. (3) Socialization of various sorghum products, Socialization of various sorghum products is needed, bearing in mind that not all regions are producing sorghum and not all people understand the benefits and processing.; and 4. Strengthening CSE and SEU, entrepreneurship program of sorghum us base food alternative has been carried out and finally formed the Center of Sorghum Entrepreneur (CSE) UWKS should be implemented continuously in the development of educational entrepreneurship programs in order to create new entrepreneurs (Sorghum Entrepreneurship Unit / SEU) and finally to develop the Sorghum Entrepreneur based product business, which until now formed 30 SEUs that are specific to each product (Figure 3). So as the strengthening of national food stocks is specifically carried out at sorghum production centers in the regions. The distribution of sorghum-producing regions in Indonesia in East Timor is Lamongan, Bojonegoro, Pasuruan, Probolinggo, Bangkalan, Sampang, Pamekasan, Sumenep, while in Central Java Jepara Regency and in West Java Regency Bandung. In addition there are also in Lampung, Makassar, and NTB (Noerhartati, 2018); (Candrawati, Noerhartati, Sariono, Chamidah, \& Yunarko, 2019).

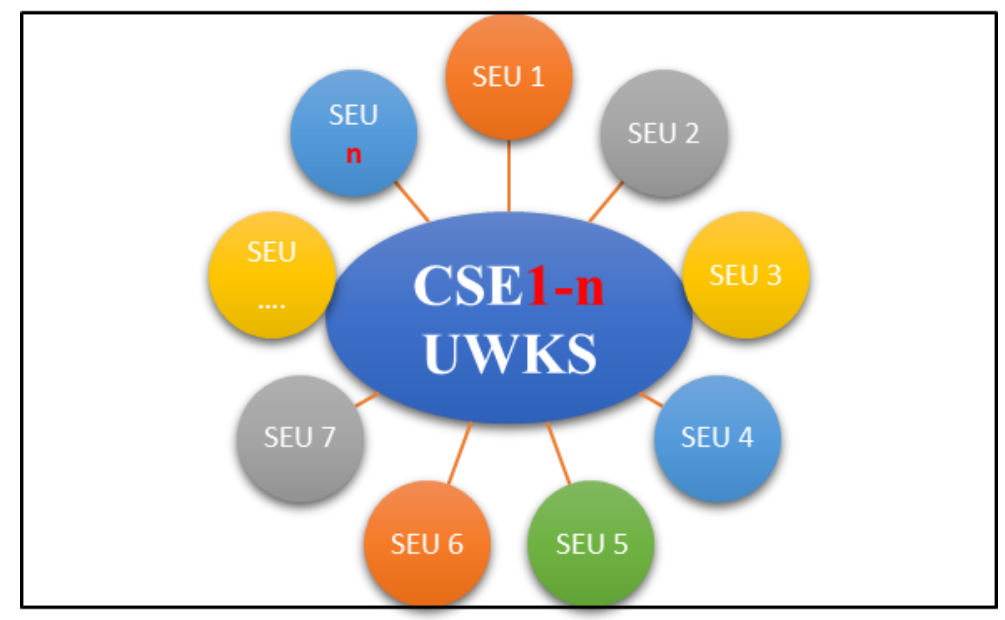

Figure 3. Strengthening CSE and SEU

\section{CONCLUSION}

Sorghum can be used as a National food Stock facing a crisis and Pandemic Covid-19, sorghum food stock in the form of grains, rice, flour, soft brand sorghum, and various processed sorghum. The strengthening of national food stocks is specifically carried out at sorghum production centers in the regions, by forming Center of Sorghum Entrepreneur (CSE) and Sorghum Entrepreneurship Unit (SEU) in each region.

\section{REFERENCES}


Adams, J. G., \& Walls, R. M. (2020). Supporting the Health Care Workforce During the COVID-19 Global Epidemic. JAMA, 323(15), 1439. https://doi.org/10.1001/jama.2020.3972

Ardabili, G. S., Zakaria, R. A., \& Zare, N. (2015). In Vitro Induction of Polyploidy in Sorghum bicolor L. CYTOLOGIA, 80(4), 495-503. https://doi.org/10.1508/cytologia.80.495

Badan Pusat Statistik. (2019). Statistical Yearbook of Indonesia 2019. Jakarta: Badan Pusat Statistik.

Baker, S. R., Farrokhnia, R. A., Meyer, S., Pagel, M., \& Yannelis, C. (2020). How Does Household Spending Respond To An Epidemic? Consumption During The 2020 Covid-19 Pandemic (No. 26949). Cambridge.

Baldwin, R., \& Mauro, B. W. di. (2020). Economics in the Time of COVID-19. London: CEPR Press.

Banerjee, D. (2020). How COVID-19 is overwhelming our mental health. Retrieved from nature india website: https://www.natureasia.com/en/nindia/article/10.1038/nindia.2020.46

Bolarinwa, O. D., Ogundari, K., \& Aromolaran, A. B. (2020). Intertemporal evaluation of household food security and its determinants: evidence from Rwanda. Food Security, 12(1), 179-189. https://doi.org/10.1007/s12571-019-00986-z

Campi, M., Dueñas, M., \& Fagiolo, G. (2020). Specialization in food production, global food security and sustainability. Retrieved from RED Investigadores de Economia website: https://repositorio.redinvestigadores.org/handle/Riec/49?locale-attribute=en

Candrawati, E., Noerhartati, E., Sariono, J. N., Chamidah, D., \& Yunarko, B. (2019). Perlindungan Hukum Bagi Konsumen Atas Temuan Sorgum Sebagai Bahan Pangan Alternatif Pengganti Beras. PROSIDING SEMINAR NASIONAL CENDEKIAWAN, 2. https://doi.org/10.25105/semnas.v0i0.5898

Martin, V., Alary, V., Daburon, A., Ali, A., Osman, M. A., Salah, E., ... Dutilly, C. (2020). Food Security, Poverty and Diversification: Relative Contribution of Livestock Activities on Small-scale Farms in Egypt. African Studies Quarterly, 19(1).

Noerhartati, E. (2018). Evaluation of Entrepreneurship Education on Development Program of Product Sorghum. International Journal of Engineering \& Technology, 7(3.30), 400. https://doi.org/10.14419/ijet.v7i3.30.18342

Rizal, J. G., \& Wedhaswary, I. D. (2020). "Pandemi Covid-19, Apa Saja Dampak pada Sektor Ketenagakerjaan Indonesia?". Retrieved from Kompas.com website: https://www.kompas.com/tren/read/2020/08/11/102500165/pandemi-covid-19-apa-saja-dampak-padasektor-ketenagakerjaan-indonesia-?page $=$ all

Wang, C. J., Ng, C. Y., \& Brook, R. H. (2020). Response to COVID-19 in Taiwan. JAMA, 323(14), 1341. https://doi.org/10.1001/jama.2020.3151

Wang, H., Zhang, Y., Lu, S., \& Wang, S. (2020). Tracking And Forecasting Milepost Moments Of The Epidemic In The Early-Outbreak: Framework And Applications To The COVID-19. Retrieved from medRxiv website: https://www.medrxiv.org/content/10.1101/2020.03.21.20040139v1

Wu, H.-Y., Lin, Y.-J., Chien, F.-L., \& Hung, Y.-M. (2011). A study on the relationship among supplier capability, partnership and competitive advantage in Taiwan's semiconductor industry. International Journal of Electronic Business Management, 9. 